LYSTVAN K. V.

Institute of Cell Biology and Genetic Engineering NAS of Ukraine,

Ukraine, 03143, Kyiv, Acad.Zabolothoho str., 148, e-mail: lystvan@icbge.org.ua, (050) 387-18-68

\title{
STUDY OF INFLUENCE OF ASCORBIC ACID, REDUCING SUGARS AND METHYLDOPA ON BETALAINS CONTENT IN CELOSIA CRISTATA L. CALLUS
}

\begin{abstract}
Aim. The aim of the present work is to investigate the influence of reducing sugars, ascorbic acid and methyl DOPA as one of the DOPA decarboxylase inhibitors on total amount and spectrum of betalains in the callus culture of cockscomb Celosia cristata L. (Amaranthaceae).
\end{abstract} Methods. Tissue culture methods, analytical highperformance liquid chromatography (HPLC), spectrophotometry. Results. Adding of some reducing sugars (1\% of glucose, arabinose or rhamnose) to the media does not increase the total betalains content. Ascorbic acid at a concentration of $5 \mathrm{mM}$ also does not significantly affect the amount of betalains, but considerably inhibit the callus growth. Moreover, ascorbic acid causes significant decreasing of the dopamine content and the normalized concentration of the main betacyanin pigment of the callus - amaranthin. Investigations have begun to study the effects of DOPA-decarboxylase inhibitors on the content of betalains and dopamine. Increased level of betalains in the callus in the presence of all used concentrations of methylDOPA was aobserved. The necessity of use of ascorbic acid or another stabilizer of methylDOPA in order to prevent oxidation of this inhibitor has been established. Conclusions. The data obtained suggest that methylDOPA as well as, probably, other inhibitors of DOPA decarboxylase can influence on betalains level in callus culture, so their use may be a potential strategy for these pigments content increasing.

Keywords: Celosia cristata L. betalains, dopamine, callus culture.

Betalains are nitrogen-containing pigments, which occur in plants of most families of the Caryophyllales order (e.g. Amaranthus and Beta species (Amaranthaceae), Portulaca (Portulacaceae), different cacti genera etc.). They are divided into two groups: red-violet betacyanins and yellow-red betaxanthins. Betalains have an excellent antioxidant activity [1-3] and used as a colorant in food industry [4]. The most known representative of this class of pigments is betanin the main pigment of beetroots Beta vulgaris. In vitro cultures of some plant species also could be an alternative source for obtaining of these pigments [5]. However, biosynthetic pathways of betalains are studied insufficiently, so the investigation of factors which could influence the total amounts and spectrum of these pigments in different plants is important.

The callus culture of cockscomb Celosia cristata L. (Amaranthaceae) is cultivated in the Institute of Cell Biology and Genetic Engineering NAS of Ukraine for many years. Production of significant amounts of betalains was noted in this culture. These pigments was investigated recently and new ones - celoscristatin and its isomers were isolated and characterized [6]. Moreover, a large amount of dopamine was discovered in this culture [6]. This catecholamine serves as an animal neurotransmitter and was found also in some plants species, e.g. legume Mucuna pruriens (Fabaceae) and Papaver bracteatum (Papaveraceae). Dopamine is a biosynthetic precursor of some betalains, mainly of dopamine-based betaxanthin and some dopamine-derived betacyanins pigments which contain 2-decarboxy-betanidin as a core structure. So the fluctuations of dopamine content as well as of the content of the main precursor of all betalains - L-3,4dihydroxyphenylalanine (DOPA) - may affect the total amount of these pigments in plant cells. It can be assumed that some agents which can decrease the DOPA and/or dopamine oxidation rate may lead to the increase of betalains content. In the present work we have studied the influence of some of them - reducing sugars, ascorbic acid and methylDOPA as one of the DOPA decarboxylase inhibitors, on betalains and dopamine content of the callus culture of $C$. cristata.

\section{Materials and methods}

The initial callus culture of C.cristata was cultivated on a $\mathrm{KC}$ medium, an MS [7] medium supplemented with $1 \mathrm{mg} / \mathrm{L}$ of $2.4-\mathrm{D}, 1 \mathrm{mg} / \mathrm{L}$ of

\footnotetext{
${ }^{\circ}$ LYSTVAN K. V.
} 
BAP and $1 \mathrm{~g} / \mathrm{L}$ of casein hydrolysate. Modified media had the same macro salts and phytohormones composition, and appropriate supplements were added to this base medium depending on the purpose of the experiment. To determine the effect of ascorbic acid and methylDOPA - ascorbic acid sterilized by filtration was added at final concentrations of 5 and $10 \mu \mathrm{M}$; the used concentrations of methylDOPA were $0.125,0.25$, $0.5,1$, and $2 \mathrm{mM}$. In the experiments with different sugars, $1 \%$ of some of them (glucose, arabinose, rhamnose and sucrose) was added to the standard media containing $3 \%$ of sucrose. The growth index was determined for the evaluation of callus growth rate. It was calculated as the callus fresh weight ratio at the end/at the beginning of the passage.

For the study of dopamine and total betalains content, the samples of air-dried (10-60 mg) or fresh $(0.3-1 \mathrm{~g})$ callus were homogenized manually with distilled water or $1 \%$ aqueous formic acid. Preliminarily weighed biomass was ground in a mortar or by the ball milling; an appropriate amount of extractant was added. The suspensions were quantitatively transferred to a test tube and centrifuged at $14000 \mathrm{~g}$ for 7-10 $\mathrm{min}$. The supernatant was used for spectrofotometric measurements or HPLC-DAD analyses without any further purification.

For the study of dopamine content or a spectrum of betalain pigments, a Shimadzu 10AVP HPLC system (Kyoto, Japan) equipped with a SPDM10AVP photodiode array detector was used. Reversed phase chromatography was performed with a $250 \mathrm{~mm}$ x 4.6 i.d. $\mathrm{mm}, 5 \mu \mathrm{m}$, Zorbax Eclipse XDB-C18 chromatographic column (Agilent, USA) with a Symmetry C8 Sentry Guard Cartridge, 20 $\mathrm{mm} \times 3.9 \mathrm{~mm}$ i.d., $5 \mu \mathrm{m}$ (Waters, USA). For the separation, a gradient system was used: $97 \% \mathrm{~A}$ and $3 \% \mathrm{~B}-0 \mathrm{~min} ; 70 \% \mathrm{~A}$ and $30 \% \mathrm{~B}-15 \mathrm{~min}$, with $1 \%$ aqueous formic acid (A) and acetonitrile (B). The column was thermostated at $40^{\circ} \mathrm{C}$. The injection volume was $10 \mu \mathrm{l}$, the flow rate -0.8 $\mathrm{mL} / \mathrm{min}$. Eluates were followed at $\lambda 272 \mathrm{~nm}$.

The amount of betacyanins, betaxanthins and the total amount of betalains were determined by measuring of optical density of the extract at the different wavelengths (476, 538 and $600 \mathrm{~nm}$ ), following by counting the amount of betacyanins, betaxanthins and the total amount of betalains by the Nilsson method [8]. All amounts were expressed as mg per $1 \mathrm{~g}$ dry (DW) or fresh (FW) weight of callus. Spectrofluorometer Fluorat-02-
Panorama used in the spectrophotometric mode was utilized for these measurements.

Statistical processing of the results was performed using descriptive statistics. In the description of the content of betalains and dopamine as well as callus growth rates, the values are presented in the form $M \pm m$, where $M$ is the average value, $\mathrm{m}$ is the standard deviation.

\section{Results and discussion}

The effect of some reducing sugar on betalains content has been studied. There are two functionally different classes of mono- and disaccharides: reducing and non-reducing depending on the presence of hemiacetal unit in their molecule. In our study, three monosacharides possessing the reducing properties (glucose, arabinose and rhamnose) were used. As we shown earlier [6], from these three monosacharides only glucose can be used by the investigated Celosia callus as a source of energy and carbon, while arabinose and rhamnose are non-metabolizable and could demonstrate their reducing abilities without being metabolized by cells. The sugars were added to the base medium, containing $3 \%$ of sucrose, non-reducing one, in a $1 \%$ concentration. Media with the $4 \%$ sucrose $(3 \%+1 \%)$ was used for comparison.

The results of the measurements of growth indexes and betalains content were shown on Fig. 1 and Fig. 2. The extra adding of $1 \%$ of sucrose results in about $20 \%$ growth index increasing; the same occurs in the case of addition of other metabolizable sugar - glucose. No effect on callus growth has been observed for all three used nonmetabolizable sugars. Moreover, total betalain content was not affected by any of the used sugars (Fig. 2). So the use of reducing sugars cannot be recommended to increase of betalains content in the cockscomb callus culture.

Ascorbic acid adding at a concentration of 5 $\mathrm{mM}$ did not significantly affect the concentration of betalains in callus culture; however, significant inhibition of growth of the callus is noted (Fig. 3). The content of dopamine is decreased by about $25 \%$ (Fig. 3). With increasing of concentrations of ascorbic acid up to $10 \mathrm{mM}$, investigated culture lost their color and died. So the use of these concentrations of ascorbic acid also cannot be recommended to increase of these pigments content in the callus culture of $C$. cristata. 
Lystvan K. V.

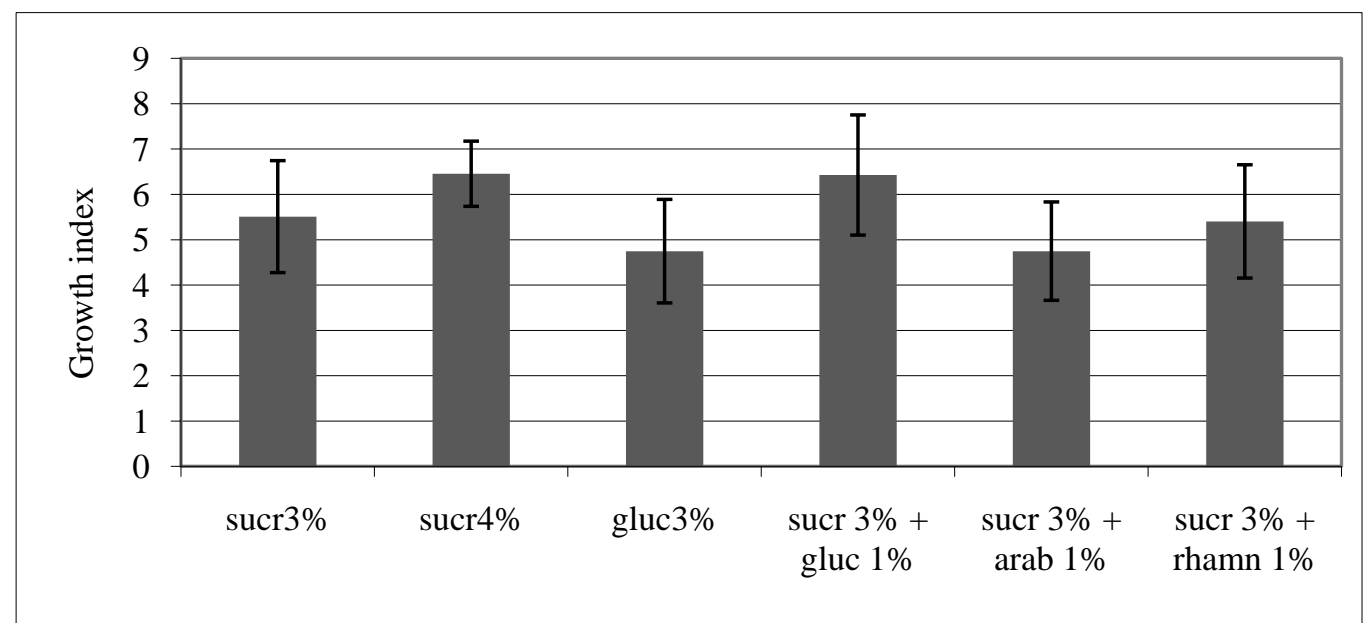

Fig. 1. Growth rates of calli cultivated on media with adding of different sugars.

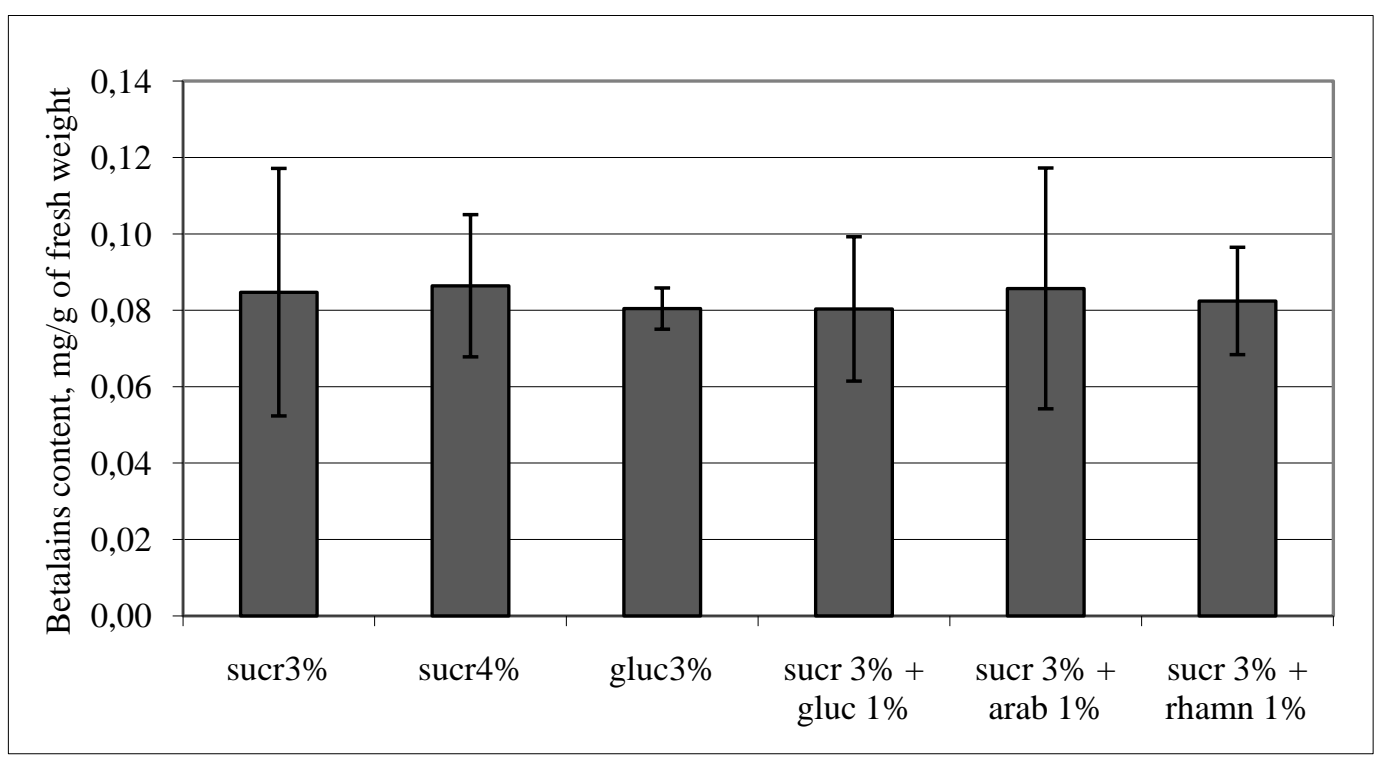

Fig. 2. Total betalains content in calli cultivated on media with adding of different sugars.

We studied the changes of betalains spectrum under the ascorbic acid influence. The results are presented on Fig. 4. The significant decrease of the normalized concentration of the main pigment (retention time $-10.6 \mathrm{~min}$ ) was occurred. As we know from our previous investigation [6], this main betacyanin of this Celosia callus is amaranthin. The mechanism of such influence of ascorbic acid on amaranthin content remains unclear.

Experiments were carried out also to investigate the quantitative and qualitative changes of betalains and dopamine depending on DOPAdecarboxylase inhibitors. Dopamine is thought to be produced in a plant cell by two main ways - by the hydroxylation of tyramine or/and decarboxylation of L-DOPA. We suggested that high dopamine content in the callus culture is owing to high activity of DOPA-decarboxylase, which results in rapid decarboxylation of DOPA, so a portion of DOPA does not participate in the formation of betalains. Therefore, the use of inhibitors of DOPA-decarboxylase should increase the DOPA concentration in the cell and, respectively, the betalains content.

We used one of such DOPA-decarboxylase inhibitor - methylDOPA. During the work it was found that some stabilizing additives should be added to the methylDOPA working solutions. Without such ones methylDOPA being adding to the nutrient media, start to polymerize and darkcolored polymeric melanins were appeared. Accordingly, the concentration of methylDOPA that remains in the media decreases and it is not known exactly how much inhibitor is contained in media at a given moment. 

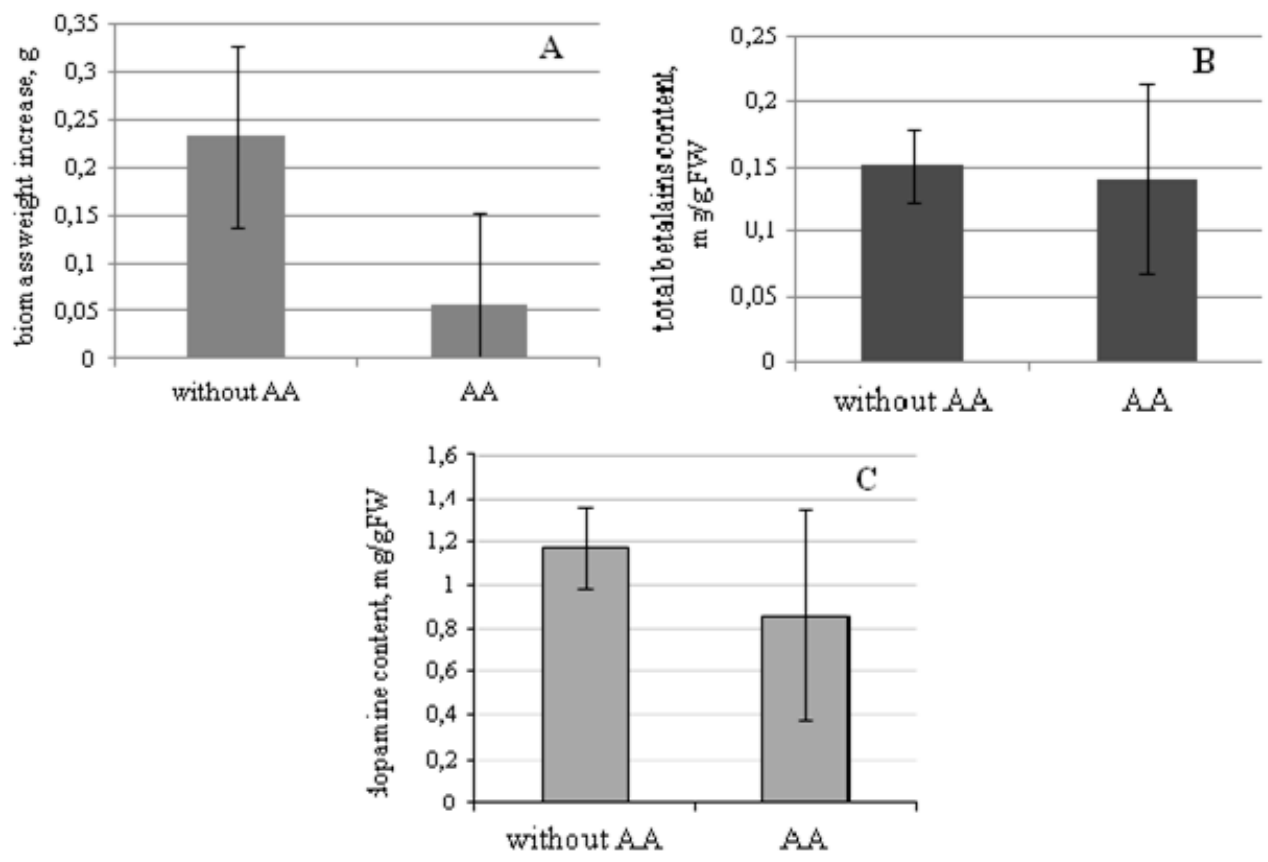

Fig. 3. Ascorbic acid (AA, $5 \mathrm{mM}$ ) influence on the growth rates of biomass (A), content of total betalains (B) and dopamine (C) in Celosia cristata callus.

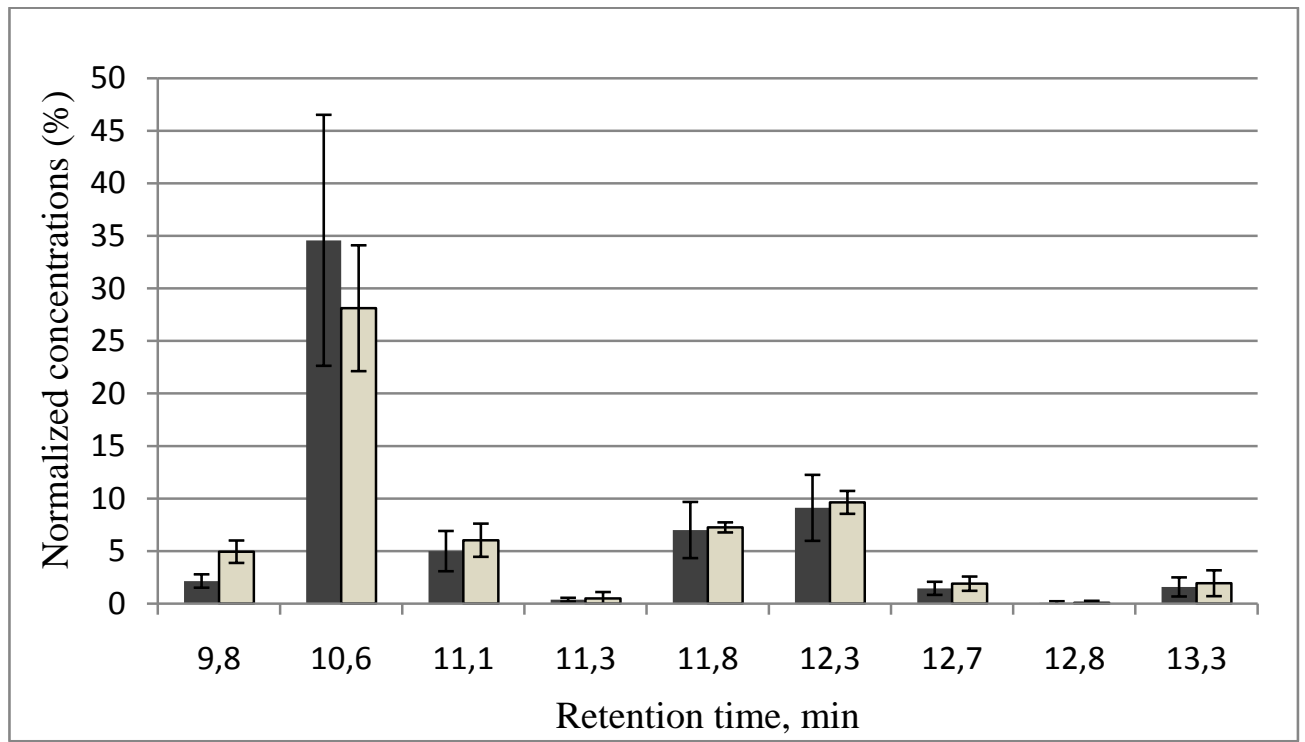

Fig. 4. Normalized concentrations (\%) based on peak areas in chromatograms of the main betalains of Celosia cristata L. callus culture cultivated on media without (dark bar) and with (light bar) ascorbic acid (5 MM).

However, even under such conditions, measurements of the amount of betalains in callus in the presence of different concentrations of methylDOPA showed that the pigments content is increased in a dose-dependent manner (Fig. 5). It should be mentioned that such change of total betalains content is provided by rising of both betacyanins and betaxanthins amount. This increase of betalains content is not very large - about $20 \%$ at the highest of the investigated concentrations of used inhibitor ( $2 \mathrm{mM})$ - but this may occurs due to the aforementioned loss of the inhibitor during the cultivation, so it should be suggested that the higher concentrations of methylDOPA will have more pronounced effect.

In any case, these data shown that methylDOPA as well as, probably, other inhibitors of DOPA decarboxylase can influence on betalains amount in callus culture, so their use may be a potential strategy for these pigments content increasing and continuation of experiments in this direction is important. 


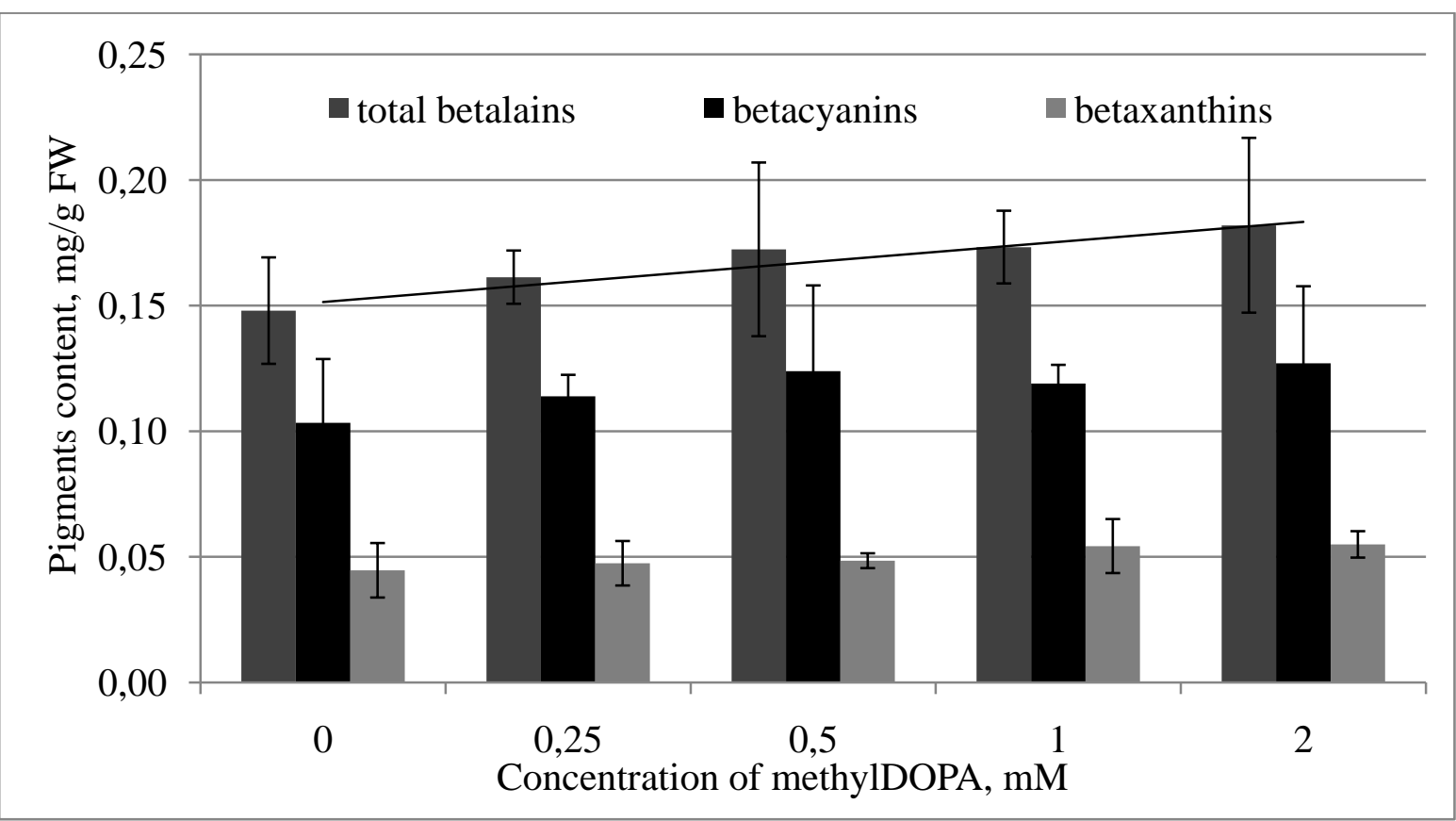

Fig. 5. Influence of different methylDOPA concentrations (MM) on the total betalains, betacyanins and betaxantins content of Celosia cristata callus culture.

\section{Conclusions}

Adding to the media of some reducing sugars ( $1 \%$ of glucose, arabinose or rhamnose) does not increase the total betalains content. Ascorbic acid at a concentration of $5 \mathrm{mM}$ also does not significantly affect the amount of betalains, but considerable inhibit the callus growth. Moreover, ascorbic acid causes significant decreasing of the dopamine content and the normalized concentration of the main betacyanin pigment of the callus amaranthin. Instead, increased level of betalains in the callus in the presence of all used concentrations of methylDOPA was observed. The necessity of use of ascorbic acid or another stabilizer of methylDOPA in order to prevent oxidation of the inhibitor has been established.

The data obtained suggest that methylDOPA as well as, probably, other inhibitors of DOPA decarboxylase can influence on betalains amount in callus culture, so their use may be a potential strategy for these pigments content increasing.

We are grateful to Germplasm bank of world flora of Institute of Cell Biology and Genetic Engineering of NAS of Ukraine for providing an initial callus culture of Celosa cristata $\mathrm{L}$.

\section{References}

1. Kanner, J., Harel, S., Granit, R. Betalains - A new class of dietary cationized antioxidants. J. Agric. Food Chem. 2001. No. 49. P. 5178-5185. doi: 10.1021/jf010456f.

2. Kim Y., Hwang J., Sung S., Jeon Y., Jeong J., Jeon B., Moon S., Park P. Antioxidant activity and protective effect of extract of Celosia cristata L. flower on tert-butyl hydroperoxide-induced oxidative hepatotoxicity. Food Chem. 2015. 168. P. 572-579. doi: 10.1016/j.foodchem.2014.07.106.

3. Khan M.I., Giridhar P. Plant betalains: Chemistry and biochemistry. Phytochemistry. 2015. Vol. 117. P. 267-295. doi: 10.1016/j.phytochem.2015.06.008.

4. Azeredo H.M.C. Betalains: properties, sources, applications, and stability - a review. Int. J. Food Sci. Technol. 2009.44. P. 2365-2376. doi: 10.1111/j.1365-2621.2007.01668.x

5. Georgiev V., Ilieva M., Bley T., Pavlov A. Betalain production in plant in vitro systems. Acta Physiol. Plant. 2008. 30. P. 581593. doi: 10.1007/s11738-008-0170-6.

6. Lystvan K., Kumorkiewicz A., Szneler E., Wybraniec S. Study on betalains in Celosia cristata Linn. callus culture and identification of new malonylated amaranthins. J. Agric. Food Chem. 2018. No. 66 (15). P. 3870-3879. doi: 10.1021/acs.jafc.8b01014.

7. Murashige T., Skoog F. A revised medium for rapid growth and bioassays with tobacco tissue cultures. Physiol. Plant. 1962. 15. P. 473-497.

8. Nilsson T. Studies into the pigments in beetroot (Beta vulgaris L. ssp. vulgaris var. rubra L.). Lantbrukshoeg Ann. 1970. Vol. 3. P. 179-219. 


\section{ЛИСТВАН К. В.}

Інститут клітинної біології та генетичної інженерії НАН України,

Україна, 03143, м. Київ, вул. Акад. Заболотного, 148, е-таil: lystvan@icbge.org.иа

\section{ДОСЛІДЖЕННЯ ВПЛИВУ АСКОРБІНОВОЇ КИСЛОТИ, ВІДНОВНИХ ЦУКРІВ ТА МЕТИЛДОПА НА ВМІСТ БЕТАЛАЇНІВ У КАЛЮСІ CELOSIA CRISTATA L.}

Mema. Дослідження впливу відновних цукрів, аскорбінової кислоти та метилДОПА як одного з інгібіторів ДОПА декарбоксилази на загальну кількість і спектр беталаїнів у калюсній культурі целозії гребінчастої Celosia cristata L. (Amaranthaceae). Методи. Методи культури тканин, аналітична високоефективна рідинна хроматографія (BEPX), спектрофотометричні методи. Результати. Додавання до середовища 1\% низки відновних цукрів (глюкози, арабінози або рамнози) не викликає посилення біосинтезу беталаїнів. Аскорбінова кислота у концентрації 5 мМ також не викликає помітної зміни загальної кількості беталаїнів, але значно інгібує ріст калюсу. Крім того, аскорбінова кислота призводить до зниження вмісту дофаміну та відносної концентрації основного бетаціаніну калюсу - амарантину. Розпочата робота з вивчення впливу інгібіторів ДОФА_декарбоксилази на вміст беталаїну та дофаміну. Встановлено підвищення кількості беталаїнів у калюсі целозії гребінчастої в присутності метилДОФА; встановлено необхідність застосування в подальших експериментах аскорбінової кислоти чи іншого стабілізатора для запобігання окиснення інігібітора. Висновки. Отримані дані дають підстави вважати, що метилДОФА як, можливо, і інші інгібітори ДОФА декарбоксилази можуть бути засобом підвищення кількості беталаїнів у калюсній культурі.

Ключові слова: Celosia cristata L. беталаїни, дофамін, калюсна культура. 